\title{
Laboratory Room Security Safety System Electrical Engineering Department using Digital Access Code
}

\author{
Deitje Sofie Pongoh \\ Department of Electrical \\ Engineering \\ Manado State Polytechnic
}

\author{
Ronny Katuuk \\ Department of Computer \\ Engineering \\ Manado State Polytechnic
}

\author{
Marson James Budiman \\ Department of Computer \\ Engineering \\ Manado State Polytechnic
}

\begin{abstract}
In line with current technological developments, the role of an automation control tool is needed without exception in a room security system that requires a very high level of security. Because of the reason for the lack of security and comfort in the electrical engineering laboratory room with a lot of equipment in practice, the authors made a system to answer these needs. For this reason the writer will create a Microcontroller-Based Door Access System Using Arduino which gives room users a sense of security and comfort when they use the room. To achieve this goal the author approaches the system design method, namely the design of hardware and software systems such as, designing tools, circuits and programming on applications and testing tools. By using selenoid sequences, relays, microcontrollers and bluetooth are connected to the door. The result of this system testing is to use Arduino to access other than the user can not enter the room. And it is expected that in development can maximize the performance of the matlab application to Arduino because in this test the application cannot be tested.
\end{abstract}

\section{Keywords}

Microcontroller, Arduino Uno, room security, access code

\section{INTRODUCTION}

The development of technology makes many people want to make a tool that can facilitate the work to be more practical and safe when it will be left behind. That way the development of this technology also affects the development of technology in the field of control automation and microcontroller. With the development in the field of control automation technology and microcontrollers [1][2], now many tools with this field are made to support the work in this field. In line with current technological developments, the role of an automation control tool is needed without exception in a room security system that requires a very high level of security[4][6]. Microcontroller is a control system that is made to control and control electronics and can generally store programs [3][4]. With a microcontrler we can control the security of a room. Open door control is a system that can limit a person to enter or be in a room. [5][8]This system will limit the user by using a microcontroller system on the door digitally. By using a microcontroller system as a door access control tool, the laboratory room manager has the right to the room with the comfort and security that is maintained. The electrical engineering department has many rooms that can be accessed by many people. The system used in each room is more than the laboratory room is still manual so that each room can still be used by people who are not interested. With a room that can be accessed by many people, it is not possible for the room to become unsafe and uncomfortable. Each room needs a control system to limit the room so that users of the room not only feel comfortable when using the room but also feel safe when leaving their belongings in the room.

\section{METHODOLOGY}

\subsection{Labority Research}

Conduct experiments or experiments and test the components needed in compiling the series in the Electrical Engineering Laboratory of Electrical Engineering Department. The hardware and software specifications used are:[10][11]

a. Hardware : Computer, Arduino microcomputer, DC motor, Serial communication interface with RS-232, Keypad, LCD

b. Software: Arduino programming language, Language $\mathrm{C}$

\subsection{System planning}

1) Input

The keypad as input and send input data to the 2) Process microcomputer

The computer will send the program to the microcontroller so that the microcontroller processes data from the inpur keypad as a digital code set_point and provides an output signal to DC motors and LCD

3) Output

The door will open if the password is entered correctly through the signal output to the relay and display to the LCD as monitoring password abuse.

4) Experiment

That is the method of designing tools and applications that are used, simulating a test tool on the circuit module to function according to purpose.

The following is a general description of the way the door security system will be designed.[4] 


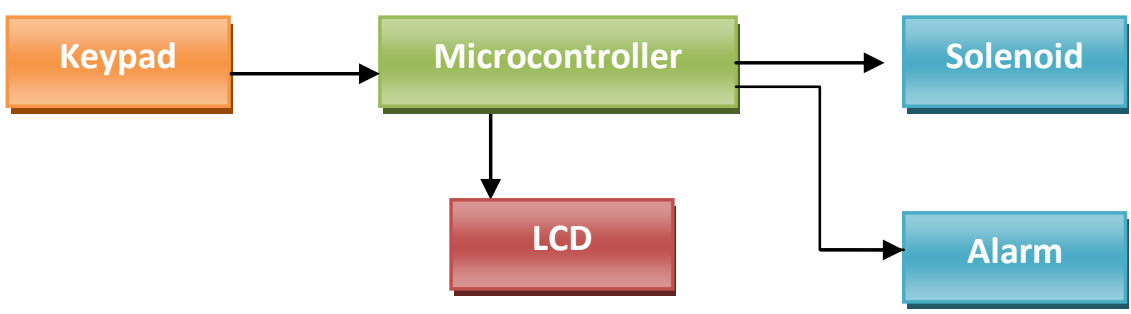

Fig 1. Workflow of the door security system

\subsection{Software Design}

The operation of this system requires a software system that is able to control all system operations. Making software used for the operation of this system must be adjusted to the characteristics of the system and guided by the processor used. In this study the processor used is the Arduino Uno microcontroller, so the programming language uses $\mathrm{C}$ language that follows the rules that exist in the PC programming language and Arduino microcontroller. Flow chart of the work system door process can be seen in Fig 2.[6]
An outline description of each step of the flow diagram of the control system diagram procedure can be explained as follows:[8]v

1. After the system is started, the routine that is first executed by the microcontroller is the initialization process.

2. Followed by the process of reading PC signal input

3. Data comparison results, if input data is detected, the first processor will activate the motor driver.

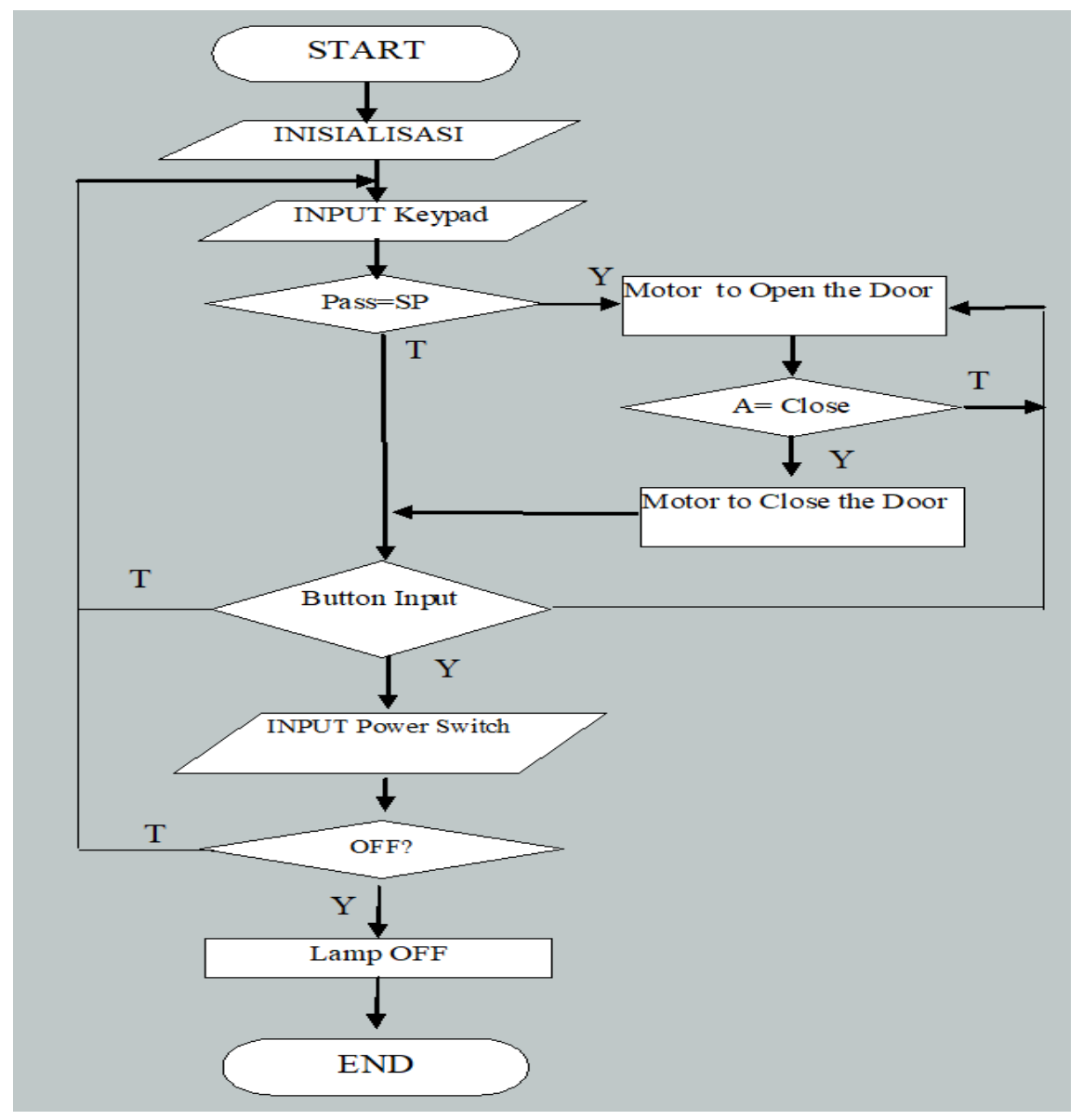

Fig 2. System Process Flow Chart 


\section{RESULTS AND DISCUSSION}

\subsection{Separate Support Parameter Testing}

After designing the system, the next step is to test the tool with program logic. Testing is done to find out the results of system performance. Testing can be done separately with the intention to test each module and test it in an integrated manner with the aim of combining all existing systems into one unit to find out its performance if it becomes an integrated system. From the testing program that has been made, it is generally done per subprogram block. Because by testing per block can be known the deficiencies contained in each block with error checking which is easier than checking all programs made. Software testing aims to find out whether this program is successful or not. In addition, to find out the reliability and accuracy of the programs made. To be able to find out the results, a separate test is carried out, including: Microcontroller Testing, .I / O testing, LCD testing, .Keypad Testing, Testing the whole system.[2]

\subsection{Microcontroller Testing}

The first step is to test the ports - Arduinio microcontroller IC ports. Port I is used as output and to serial. The results obtained are sensors that are inputted on the analog pin A0 and display the value on the serial monitor on the PC. This means that the microcontroller is ready to be used for system applications.[4][5] Peripheral Testing Input Output uses the same method as the method for testing 13 microcontroller ports. That is by connecting the I / O with the LED tester. The results obtained are continuous blinking LEDs on each port. This means that I / O is ready to be used for system applications. Keypad testing is done by displaying the results of pressing the keypad through ports 1,2,3 columns and 4,5,6,7 for lines and displayed on the LED tester. The results obtained are the LEDs that match the keystrokes[1]. This means that the keypad can be used for system applications. Testing of the display display on the LCD is done using EEPROM Emulator[3][7]. The results obtained are display data created can be observed directly on the LCD[2]. Data and methods for displaying data on the LCD depend on the data created and the LCD initialization compiled.

\subsection{Work Description of the Overall System}

The final part is analyzing the system's reaction to diverse inputs. What is meant by various inputs is the inputs that are entered both input numbers and special characters that have been entered into the memory database and that have not been entered into memory. In memory, 4 codes will be saved as the set point. If you enter 4 access codes on the LCD display it will read "Open Door" so the relay will be connected and the door solenoid will open, but if 4 access codes are entered and the LCD display reads "wrong access code" then the door relay is not connected and will sound the alarm as a sign of the access code is not the same as the set point stored in memory. Table 1 . shows the design results of pressing the keypad in the form of setpoint and access code that will be compared by the microcontroller. In completing the setpoi nt there are two spaces provided for two room users
Table 1. Fill in the set point and access code

\begin{tabular}{|c|c|c|l|}
\hline No. & $\begin{array}{c}\text { Access code } \\
\text { (Set Point) }\end{array}$ & $\begin{array}{c}\text { Access code } \\
\text { (Password) }\end{array}$ & \multicolumn{1}{|c|}{ Ket. } \\
\hline 1. & 1234 & 1234 & $\begin{array}{l}\text { Aktive } \\
\text { Solenoid }\end{array}$ \\
\hline 2. & 1234 & 2134 & Aktive Alarm \\
\hline 3. & 2222 & 2222 & $\begin{array}{l}\text { Aktive } \\
\text { Solenoid }\end{array}$ \\
\hline 4. & 2222 & 3232 & Aktive Alarm \\
\hline 5. & 2843 & 2843 & $\begin{array}{l}\text { Aktive } \\
\text { Solenoid }\end{array}$ \\
\hline 6. & 2843 & 8426 & Aktive Alarm \\
\hline 7. & 3573 & 3573 & $\begin{array}{l}\text { Aktive } \\
\text { Solenoid }\end{array}$ \\
\hline 8. & 3573 & 4684 & Aktive Alarm \\
\hline 9. & 1001 & 1001 & $\begin{array}{l}\text { Aktive } \\
\text { Solenoid }\end{array}$ \\
\hline 10 & 1001 & 7901 & Aktive Alarm \\
\hline
\end{tabular}

For the set_point filling display design with the filling process as table 1 . we can see in fig 3 .

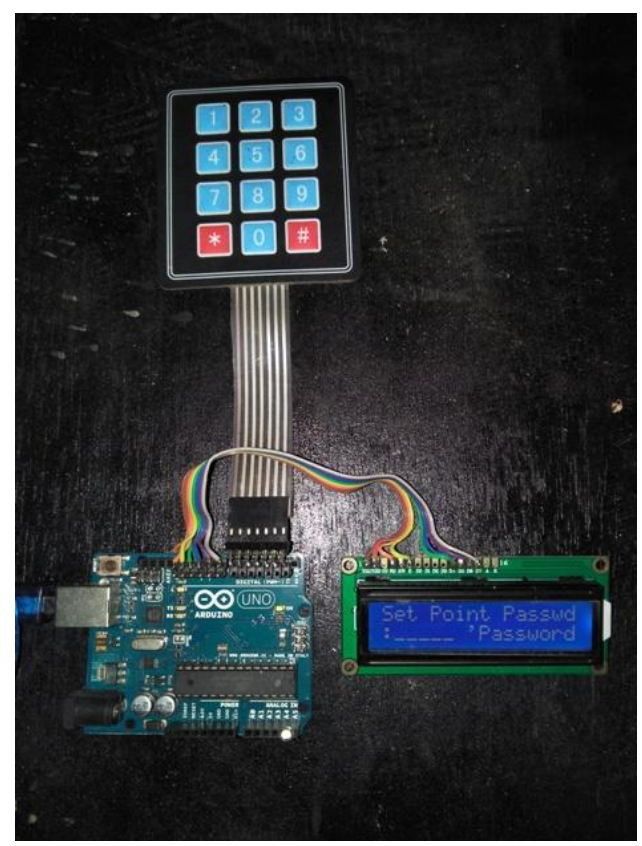

Fig 3. Set_point charging display

The Relay on process occurs when the microcontroller compares the setpoint data with the access code data. In the relay condition on the microcontroller will execute the program delay while waiting for the door to open, if the microcontroller finishes executing the delay but the door is still not opened then the processor will go directly to the enter the access code menu. Facilities in the form of a Push button are placed in the room, this functions to activate the relay when the user of the room is in the room.

\section{CONCLUSIONS}

The conclusions obtained from the results of the discussion in the previous chapters are as follows: Microcontroller is used as the main controller of the door safety system equipment for flight safety facilities. This system is made with 2 outputs consisting of relay output, and alarm output. And 3 inputs are 
input push button, keypad input, and limit switch input. This system uses a power supply with a voltage of 5 volts DC. When the power supply is turned on the system starts working where the LCD as a system indicator works. This system uses a 4 digit number combination as an access code for the set point, and an access code to access the room. In other words, the system of this tool can be used as a substitute for conventional keys to access other important rooms.

\section{ACKNOWLEDGMENTS}

Thanks to the Ministry of Research and Technology and Higher Education and manado state polythecnic, which has funded this research with competitive grants program in 2018 so as to do research and work well.

\section{REFERENCES}

[1] Alf, dkk. 2010. 8-bit AVR Microcontroller With 4/8/16/32K Bytes In-System Programmable Flash. Amerika: Atmel.

[2] Artanto, Dian. 2012. Yuk, Membuat Robot: Pembuatan Robot Virtual Dengan Software Physical e-toys + Arduino. Jakarta: Penerbit Grasindo.

[3] Banzi, Massimo. 2009. Getting Started With Arduino. Amerika: O'Reilly.

[4] Budiharto, Widodo. 2009. Membuat Sendiri Robot Cerdas Edisi Revisi. Jakarta: Penerbit Elex Media Komputindo.

[5] Jogiyanto, HM. 2001. Analisis dan Desain Sistem Informasi : Pendekatan Terstruktur Teori dan Praktek Aplikasi Bisnis. Yogyakarta: Penerbit Andi.

[6] Lukito, Yuan. 2008. Alogirtma dan Pemrogramman. Yogyakarta: Penerbit UKDW.

[7] McComb, Gordon. 2001. The Robot Builder's Bonanza. Amerika: Penerbit Mc Graw-Hill.

[8] Muchlis, Nurfajria. 2011. Pembuatan Robot Ziobot Untuk Penjejak Garis Dan Pengangkat Barang Dengan Sens or Jarak Berbasis Mikrokontroller. Jakarta: Universitas Gunadarma.

[9] Nugraha, Mara. 2011. Robot Pemandu Wisata Kebun Binatang Menggunakan Atmega8535 Dengan Sistem Suara. Jakarta: Universitas Gunadarma.

[10] Ratnakumari Challa, B Reddaiah and Srinivasa K Rao. Efficient Record Management using RFID - Arduino Technology. International Journal of Computer Applications 181(14):42-45, September 2018.

[11] Yesha A Karmakar, Krina A Suthar, Ayushi Y Vadwala and Nirali Pandya. Object Detection System using Arduino and Android Application for Visually Impaired People. International Journal of Computer Applications 181(15):42-44, September 2018. 